\title{
Endothelin-1 as a neuropeptide: neurotransmitter or neurovascular effects?
}

\author{
Michael R. Dashwood • Andrzej Loesch
}

Received: 29 July 2009 / Accepted: 22 September 2009 / Published online: 22 October 2009

(C) The Author(s) 2009. This article is published with open access at Springerlink.com

\begin{abstract}
Endothelin-1 (ET-1) is an endothelium-derived peptide that also possesses potent mitogenic activity. There is also a suggestion the ET-1 is a neuropeptide, based mainly on its histological identification in both the central and peripheral nervous system in a number of species, including man. A neuropeptide role for ET-1 is supported by studies showing a variety of effects caused following its administration into different regions of the brain and by application to peripheral nerves. In addition there are studies proposing that ET-1 is implicated in a number of neural circuits where its transmitter affects range from a role in pain and temperature control to its action on the hypothalamo-neurosecretory system. While the effect of ET-1 on nerve tissue is beyond doubt, its action on nerve blood flow is often ignored. Here, we review data generated

Concise summary Apart from its vascular effects it has been suggested that endothelin-1 (ET-1) is a neuropeptide. This is based on the histological identification of ET-1 in nervous tissue with supporting data from functional studies. Here we review a number of studies into the potential neurotransmitter role of ET-1 and discuss its confounding neurovascular effects.
\end{abstract}

\section{R. Dashwood}

Clinical Biochemistry,

University College London Medical School,

Royal Free Campus,

London NW3 2QG, UK

\section{A. Loesch}

Research Department of Inflammation,

University College London Medical School,

Royal Free Campus,

London NW3 2QG, UK

M. R. Dashwood ( $\square)$

Clinical Biochemistry, Royal Free Hospital,

Pond Street,

London NW3 2QG, UK

e-mail: m.dashwood@medsch.ucl.ac.uk

e-mail: mickeydash@hotmail.com in a number of species and using a variety of experimental models. Studies range from those showing the distribution of ET-1 and its receptors in nerve tissue to those describing numerous neurally-mediated effects of ET-1.

Keywords Endothelin · Neuropeptide - Neurovascular · Central nervous system $\cdot$ Peripheral nervous system

$\begin{array}{ll}\text { Abbreviations } \\ \text { 2DG } & \text { 2-deoxyglucose } \\ \text { ANS } & \text { autonomic nervous system } \\ \text { Ax } & \text { axon } \\ \text { At } & \text { axon terminal } \\ \text { Av } & \text { agranular vesicles } \\ \text { BVS } & \text { blood vessels } \\ \text { CSF } & \text { cerebrospinal fluid } \\ \text { CGRP } & \text { calcitonin gene-related peptide } \\ \text { CNS } & \text { central nervous system } \\ \text { Ds } & \text { dendrite spine } \\ \text { ECE } & \text { endothelin converting enzyme } \\ \text { [25 I]-ET-1 } & \text { iodinated endothelin-1 } \\ \text { ET-1 } & \text { endothelin-1 } \\ \text { ET-2 } & \text { endothelin-2 } \\ \text { ET-3 } & \text { endothelin-3 } \\ \text { ET } & \text { endothelin A receptor } \\ \text { ET } & \text { endothelin B receptor } \\ \text { GABA } & \gamma \text {-amino butyric acid } \\ \text { Gv } & \text { granular vesicles } \\ \text { ICV } & \text { intracerebroventricular } \\ \text { Idcn } & \text { intermediate dorsal cutaneous nerve } \\ \text { Lm } & \text { lateral malleolus } \\ \text { LPS } & \text { lipopolysaccharide } \\ \text { M } & \text { mitochondrium } \\ \text { mRNA } & \text { Messenger ribonucleic acid } \\ \text { NA } & \text { noradrenaline } \\ \text { NO } & \text { nitric oxide } \\ & \end{array}$




$\begin{array}{ll}\text { nNOS } & \text { neuronal nitric oxide synthase } \\ \text { NOS2 } & \text { nitric oxide synthase } 2 \\ \text { NOS3 } & \text { nitric oxide synthase } 3 \\ \text { Nsg } & \text { neurosecretory granules } \\ \text { PAG } & \text { periaqueductal gray } \\ \text { PNS } & \text { peripheral nervous system } \\ \text { SAH } & \text { subarachnoid hemorrhage } \\ \text { SCG } & \text { superior cervical ganglion } \\ \text { Sch } & \text { Schwann cell } \\ \text { TG } & \text { trigeminal ganglion } \\ \text { TH } & \text { tyrosine hydroxylase } \\ \text { V } & \text { vacuoles }\end{array}$

\section{Introduction}

Apart from its well-established vascular effects a number of studies suggest that endothelin-1 (ET-1) possesses neuropeptide properties via both $\mathrm{ET}_{\mathrm{A}}$ and $\mathrm{ET}_{\mathrm{B}}$ receptor subtypes. Perhaps one of the first publications in support of this proposition was the identification of positive immunostaining for ET-1 in neurones of the human spinal cord (Giaid et al. 1989). Furthermore, ultrastructural studies provided supporting evidence for a neurotransmitter role for ET-1 since ET-1-containing vesicles were identified in perivascular nerves of the rat basilar artery (Loesch et al. 1998). Centrally-mediated actions of ET-1 were described within a few years of its identification based on blood pressure effects elicited in rats following intracerebroventricular administration (Macrae et al. 1991a, 1993). A neurotransmitter role for ET-1 has also been proposed in the peripheral nervous system as topical application of this peptide was shown to alter nerve conduction (Zochodne et al. 1992). Since publication of these early studies there may be some doubt regarding the transmitter properties of ET-1 as many reports over the last two decades suggest rather than being a neurotransmitter the actions of ET-1 are neurovascular. In this review, of the three endothelin isoforms (ET-1, ET-2 and ET-3) we focus mainly on ET-1 and discuss early histological data providing evidence that this peptide acts on sites within the central (CNS), autonomic (ANS) and peripheral (PNS) nervous systems and studies showing the consequences of application of ET-1 to these sites. Later reports describe neurovascular effects of ET-1 suggesting that many 'neural' actions attributed to this peptide may be secondary to reduced blood flow and ischaemia of nerve tissue.

\section{Distribution of ET-1}

Following the isolation and identification of ET-1 and the description of its vascular effects (Yanagisawa et al. 1988) it was not long before this vascular endothelium-derived factor was suggested to possess neuropeptide properties. Much of this was based on the initial immunohistochemical identification of ET-1 in nerve tissue from a number of species, including rat, mouse and human (Shinmi et al. 1989; Yoshizawa et al. 1990; Lee et al. 1990; Giaid et al. 1991; Franco-Cereceda et al. 1991; Nakamura et al. 1993; Gajkowska and Viron 1996). Regarding a potential neuropeptide role for ET-1 in vascular control, ET-1-positive varicosities have been identified in perivascular nerves of the basilar artery of the rat (Loesch et al. 1998) and capybara (Loesch et al. 2005) with a similar distribution in perivascular nerves/axons in human middle cerebral artery (Loesch et al. 2004, Loesch and Burnstock 2002; Mickey et al. 2002). In the periphery ET-1 has been shown to participate in pain-related processes (Khodorova et al. 2003, 2009).

\section{ET-1 and the CNS}

\section{Distribution of ET-1 in the CNS}

Apart from describing ET-1 distribution in brain of various experimental animals this peptide has also been identified in human brain (Naidoo et al. 2004a, b). In addition, ET-1 mRNA and ET-1-like immunoreactivity has been described in human spinal cord and dorsal root ganglia with the authors concluding that ET-1 plays a part in neural transmission/modulation in addition to its vascular actions (Giaid et al. 1991).

\section{Neurotransmitter actions of ET-1 in the CNS}

The effects of drugs acting on the CNS may be studied in animals by administration into the cerebral ventricles. This technique was introduced over 50 years ago (Feldberg and Sherwood 1954) and, using such an approach, centrallymediated effects of many drugs have been described. For example, the potential central inhibitory effect of endogenous opioid peptides on the adrenal medulla, have been suggested based on intracerebrovascular (ICV) administration of the opiate receptor antagonist, naloxone, in the cat (Dashwood and Feldberg 1979). In particular, ICV injection in rats, mostly into the lateral ventricles, is commonly used for screening of compounds with potential central cardiovascular activity. Here, the tip of the cannula is placed into the 'liquor spaces', often under asceptic conditions, using stereotaxic guidance. Drugs administered by this route bypass the blood brain barrier, a structure that prevents many compounds reaching the brain when given systemically. Once injected into the cerebroventricular system compounds combine with the cerebrospinal fluid where they are able to act on many superficial brain structures. For example, the potential effects of a variety of neurotransmitters have been studied following 
administration into the aqueduct, lateral and third ventricles, routes that target various superficial structures 'adjacent' to this compartment, including the periaqueductal gray matter and the hypothalamus (See Fig. 1).

ET-1 in the CNS: neuropeptide or cerebrovascular effects?

Patterns of brain activity may be studied by measuring local cerebral energy metabolism using 2-deoxyglucose (2DG)
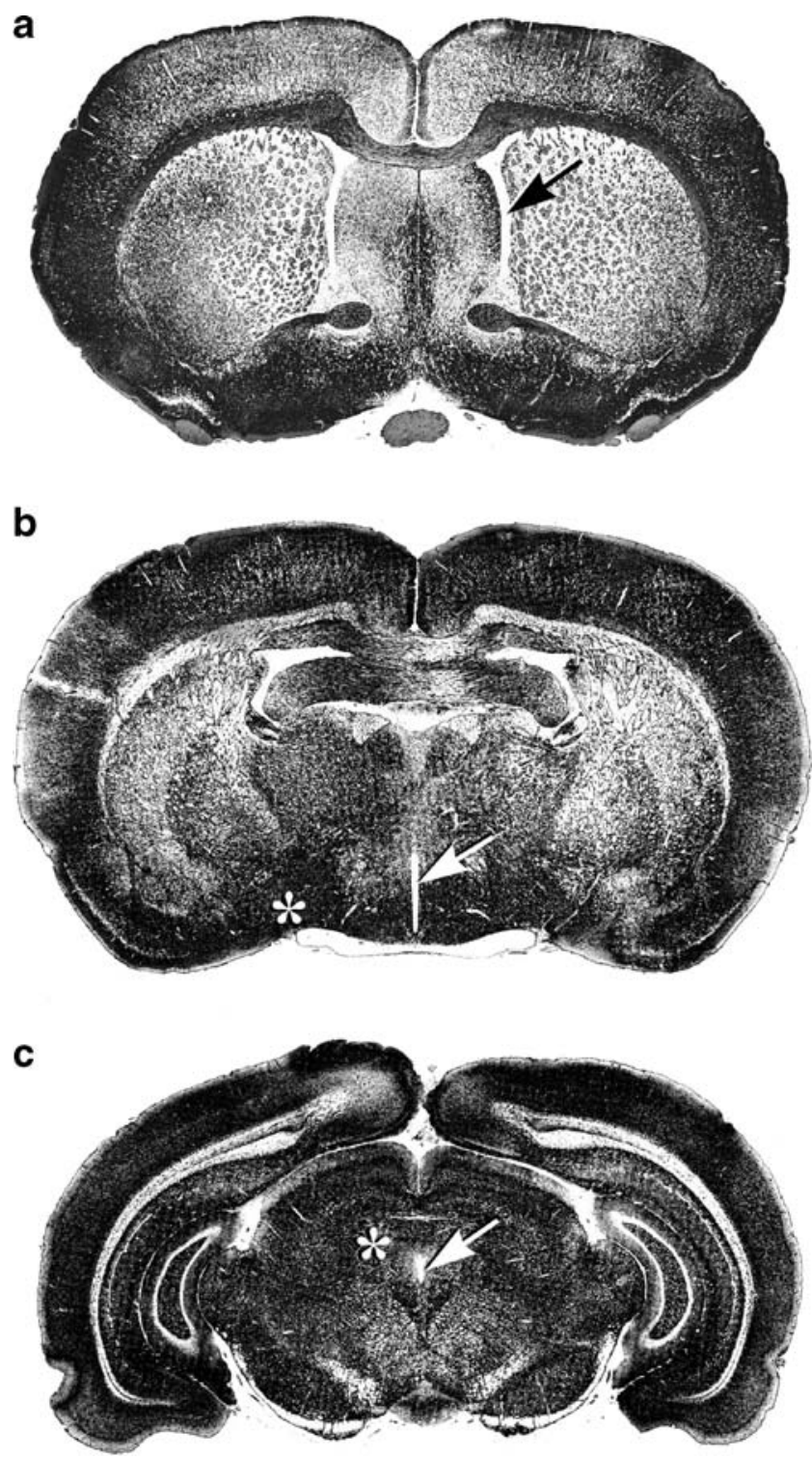

Fig. 1 Representative frontal sections of rat brain. Frontal sections of rat brain (Sudan black staining) at three different levels from rostral a to caudal c showing: in a the lateral ventricles (arrow), in b third ventricle (arrow) and thalamus-hypothalamus with supraoptic nucleus (asterisk), and in c showing aqueduct (arrow) and periaquedutcal gray area (asterisk). ET-1 adiministration to such regions has cardiovascular (D'Amico et al. 1996; McAuley et al. 1996; Macrae et al. 1991a, b; Macrae et al. 1993) and temperature-regulating effects (Fabricio et al. 2005) where altered uptake is suggested to be related to the local energy demands of nerve cells and therefore of nerve activity (Sokoloff 1978, 1984). This technique has been used to study neural 'activity' in many situations, particularly in relation to central cardiovascular control (Kostreva 1983). More recently the role of the cerebral microvasculature in supplying oxygen to 'active' nerve cells has been discussed with the proposal that $2 \mathrm{DG}$ reflects changes in blood flow rather than neural activity (Shepherd 2003). Although there is general acceptance that drugs acting when injected into the cerebral ventricles may affect neurotransmission it is clear that this may not necessarily be due to their neurotransmitter properties, more their action on the blood supply to various regions of the brain (Shepherd 2003). This suggestion was explored where the effect of ET-1 on cerebral blood flow was investigated following ICV administration. Experimental evidence was provided that ICV administration of ET-1 alters blood flow in the rat brainstem (Macrae et al. 1991b) with further data showing that this also occurs in vivo in cat cerebral resistance arterioles (Patel et al. 1996). Interestingly, where adventitial application of ET-1 and endothelin receptor antagonists was performed, $\mathrm{ET}_{\mathrm{A}}$ receptors were shown to be involved in constriction and $\mathrm{ET}_{\mathrm{B}}$ receptors with dilatation (Patel et al. 1996). These results are potentially important since in the peripheral vasculature $\mathrm{ET}_{\mathrm{B}}$-receptor activation may also elicit vasoconstriction. If a similar distribution of vascular receptors occurs in man, selective $\mathrm{ET}_{\mathrm{A}}$ antagonist treatment may have therapeutic potential in certain cerebrovascular diseases. This suggestion is supported by a study using the mixed antagonist, bosentan, in the rat middle cerebral artery occlusion model. Here, the effects of bosentan on cortical perfusion was investigated using laser Doppler flowmetry where this compound failed to reveal a significant contribution of endogenous ET-1 in this model of focal ischaemic injury. The authors conclude that selective (not 'mixed') antagonists were needed to target ET-1-induced ischemia (McAuley et al. 1996).

A similar series of studies have been reported where ICV administration (into the lateral ventricle) of ET-1 in the rat was investigated. Initially, this group studied the potential central effect of ET-1 on systemic haemodynamics and regional blood flow using a radioactive microsphere technique. Whereas low doses (5 and $15 \mathrm{ng}$ ) of ICV ET-1 were ineffective, high doses ( $>45 \mathrm{ng}$ ) were shown to cause a transient rise, followed by a fall, in systemic blood pressure. These effects were accompanied by reduced blood flow to the brain, heart, kidneys, gastrointestinal tract, portal and musculo-skeletal systems. Pharmacological extension of these studies showed that these effects were mediated solely via $\mathrm{ET}_{\mathrm{A}}$ receptors (Rebello et al. 1995). In a subsequent study this group extended their findings by comparing the effects of ICV administration of ET-1 and $\mathrm{ET}_{\mathrm{A}} / \mathrm{ET}_{\mathrm{B}}$ receptor-selective compounds. In addition to using 
microspheres, sympathetic nerve activity was monitored. Here the authors showed that many of the effects of centrally administered ET-1, such as the fall in systemic blood pressure, were accompanied by a significant decrease in sympathetic nerve activity and that these effects were mediated via $\mathrm{ET}_{\mathrm{A}}$ receptors (Gulati et al. 1997; Kumar et al. 1997).

Macrae et al. (1991b) have shown that intracisternal administration of ET-1 in the normotensive rat caused a widespread and profound ischaemia of the caudal brainstem, a region involved in central cardiovascular control. ICV ET-1 injection produced a rise in mean arterial blood pressure and concomitant elevation of plasma noradrenaline and adrenaline levels. The authors conclude that ET-1 has the potential to induce cerebral ischaemia of pathological magnitude and wisely suggest that caution is needed when drawing conclusions from ICV drug administration as ET-1 is also capable of overriding cerebrovascular autoregulatory mechanisms.

The potential for ICV administered compounds to affect the cerebral circulation is evident from recent angiographic data produced in rats exhibiting drowsiness and coma caused by brain tumor (Hekmatpanah 2007). Here, a dense vascular network in normal rats was revealed using barium sulphate contrast medium (see Fig. 2). In control animals, magnified angiograms revealed perforating microvessels that penetrate the brain and, while their diameter is too small to be detected by routine cerebral angiography, India ink injections revealed small/terminal capillaries throughout the brain (Fig. 2). Interestingly, the author (Hekmatpanah 2007) describes infarcted and ischaemic changes to microvessels of rats with brain tumours similar to those that might be expected following administration of vasoconstrictors such as ET-1.
Further evidence for a predominant involvement of the $\mathrm{ET}_{\mathrm{A}}$ receptor in the central cardiovascular effect of ET-1 was suggested where central administration of ET-1 was performed after stereotaxic placement of a needle tip into the periaqueductal gray area (D'Amico et al. 1996). These injections elicited a dose-dependent increase in mean arterial pressure but a fall in renal blood flow. Pretreatment with $\mathrm{ET}_{\mathrm{A}}$-selective antagonists reduced these effects but $\mathrm{ET}_{\mathrm{B}}$ receptor blockade was ineffective. The potential role of $\mathrm{ET}_{\mathrm{A}}$ receptors was supported by in vitro autoradiographic studies that showed dense $\left[{ }^{125} \mathrm{I}\right]-\mathrm{PD} 151242$ binding to many brain regions of the rat brain (including the periaqueductal gray area) and a paucity of $\mathrm{ET}_{\mathrm{B}}$-receptor binding sites (D'Amico et al. 1996). Again, the existence of the dense microvascular network in many brain regions, including the PAG, requires a potential vascular involvement of central ET-1 application to be considered (See Fig. 3).

A practical point that is ignored in many studies is the potential spread of what are believed 'discrete' injections and 'drug targeting'. An injection volume of $1 \mu \mathrm{l}$ will occupy an approximate area of $1 \mathrm{~mm}^{3}$. Such an area may encompass many brain nuclei that are likely to contain a dense network of cerebral vessels (Figs. 2 and 3).

In such a scenario caution is recommended if a neuropeptide action is suggested based on the effect(s) of centrally administered compounds.

Supporting evidence for a transmitter role for ET-1 has been described recently by Nabhen et al. (2009) where the co-existence of ET-1 and catecholaminergic neurones suggests that ET-1 may be a neuromodulator. Olfactory bulbs were obtained from normal rats and incubated in the presence/absence of ET-1, ET-3 and ET receptor antagonists.
Fig. 2 Cerebral vessels. Left panel. Magnification angiography of normal rat brain using barium sulphate contrast medium. There is an abundant vascular supply with many penetrating microvessels in the cortex shown in the right panel following intra-arterial injection of India ink (black regions of a haemotoxylin and eosin stains section). Scale bar $=5 \mathrm{~mm}$ for the left panel and $50 \mu \mathrm{m}$ for the right panel. Modified from Hekmatpanah Surg Neurol 2007;67:564-71
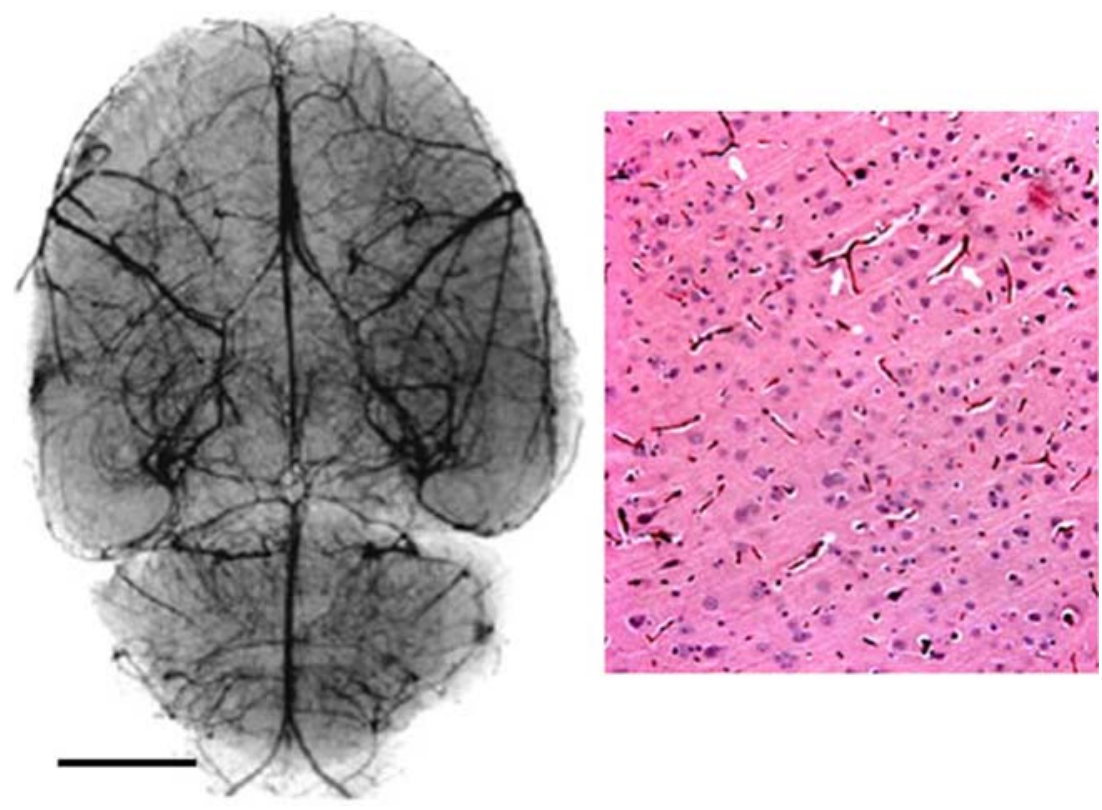


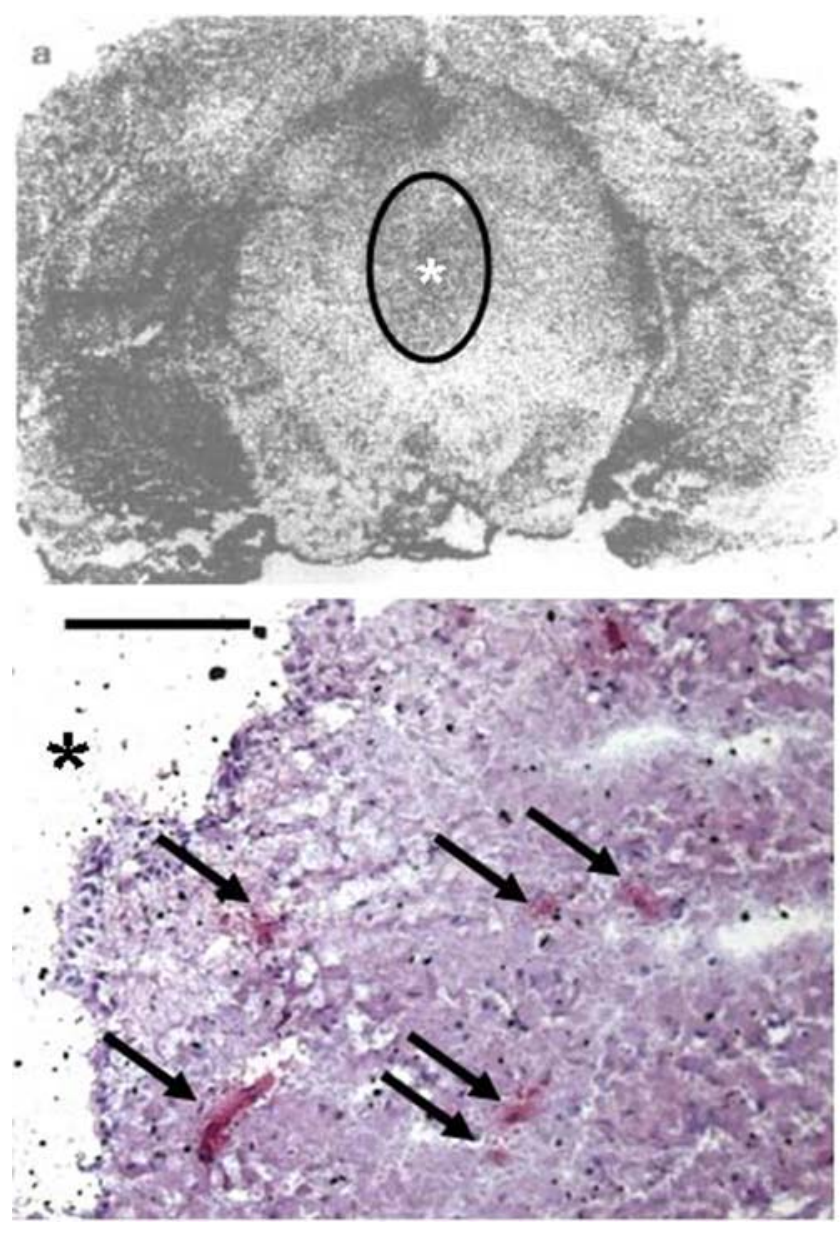

Fig. 3 ET-1 action on the periaqueductal gray area of the rat. Top panel. $\mathrm{ET}_{\mathrm{A}}$ receptors ([ ${ }^{125} \mathrm{I}-\mathrm{PD} 151252$ binding) in the rat brain identified by in vitro autoradiography (from D'Amico et al. 1996). Periaqueductal gray area (PAG) is outlined. Lower panel. Cerebral vessels of the PAG identified by immunohistochemistry (arrows indicate CD31 staining of vessel endothelium, red). (Dashwood unpublished) *indicates the aqueduct. Scale bars $=2.5 \mathrm{~mm}$ for the top and $50 \mu \mathrm{m}$ for the lower panels

Tyrosine hydroxylase $(\mathrm{TH})$ activity was determined, western blots performed and neuronal norepinephrine release measured. In the short term ET-1 and ET-3 both increase TH activity in vitro and this involved various mechanisms including increased calcium influx. This is said to be the first report showing an interaction between ET-1 and catecholaminergic transmission in olfactory bulbs and future studies are recommended to evaluate the relationship with the various other functions at this level of the brain.

CNS: ET-1 and the hypothalamo-neurosecretory system

While the endothelins and ET receptors have been detected in a number of structures throughout the CNS (Arai et al. 1990; Lee et al. 1990; Yoshizawa et al. 1990; Hemsen and Lundberg 1991; Nakamura et al. 1993; Horowitz et al.
1994; Uemura et al. 1994; Kurokawa et al. 1997; Yamada and Kurokawa 1998; Kurokawa et al. 2000), similar observations have been described in the endocrine hypothalamo-neurohypophysial secretory system that is responsible for delivering vasopressin and oxytocin to blood from neurosecretory axon terminals in the neurohypophysis (Krsmanović et al. 1991; Cao et al. 1993; Nakamura et al. 1993; Yasin et al. 1994; MosquedaGarcia et al. 1995; Kurokawa et al. 1997). Here we present selected examples of research relevant to the subject. A double immunogold co-labelling study by Nakamura et al. (1993) showed the colocalisation of immunoreactive ET-1 and vasopressin as well as ET-1 and oxytocin in subpopulations of neurohypophysial axons of the rat. Also, coexpression of genes for ET-1 and oxytocin has been revealed in the rat during pregnancy (Horowitz et al. 1994); ET-1 mRNA has been shown to be increased significantly in the supraoptic and paraventricular nuclei from early to late gestation as has oxytocin gene expression as gestation advanced. Consequently, a neuroendocrine regulatory role for ET-1 in pregnancy has been suggested (Horowitz et al. 1994). A study of ET-1 gene transcription in rat supraoptic nucleus following injury showed the dynamism of ET-1-related mechanisms, namely timeassociated changes in the expression of ET-1 mRNA and immunoreactivity to ET-1, suggesting an important role for ET-1 in neuroendocrine events following injury (Jiang et al. 2000).

Our own studies showed immunoreactive ET-1 within the rat hypothalamo-neurosecretory system, where ET-1 was detected in the cell bodies of endocrine neurons and in their processes containing neurosecretory granules (Mukherjee and Loesch 2002) (Fig. 4a). ET-1 was also detected in the axon terminals making axo-dendritic synapses; such terminals contain typical synaptic vesicles mostly small agranular vesicles (Fig. 4b). Furthermore, these studies revealed a proportion of ET-1-positive endocrine neurons and their processes, as well as ET-1-positive axon terminals making axo-dendritic synapses that were also immunoreactive for neuronal nitric oxide synthase (nNOS). (Fig. 4a, b).

The significance of nNOS/ET-1 colocalisation may be difficult to explain but suggests that cotransmission and/or neuromodulation by ET-1 and NO occurs within these nerves. In general this supports the putative roles of NO and ET-1 in the CNS and PNS (Giaid et al. 1989; Snyder and Bredt 1992; Garthwaite and Boulton 1995; Knuepfer et al. 1994; Hoyle and Burnstock 1995; Lincoln et al. 1997; Rubino et al. 1999). Similarly, physiological roles for NO/ nNOS and endothelins in hypothalamo-neurohypophysial neurosecretion may also occur (Yoshizawa et al. 1990; Yasin et al. 1993; Reid 1994; Rettori et al. 1997; Ng et al. 1999; Wang \& Morris 1999; Costa et al. 2000; Kurokawa 


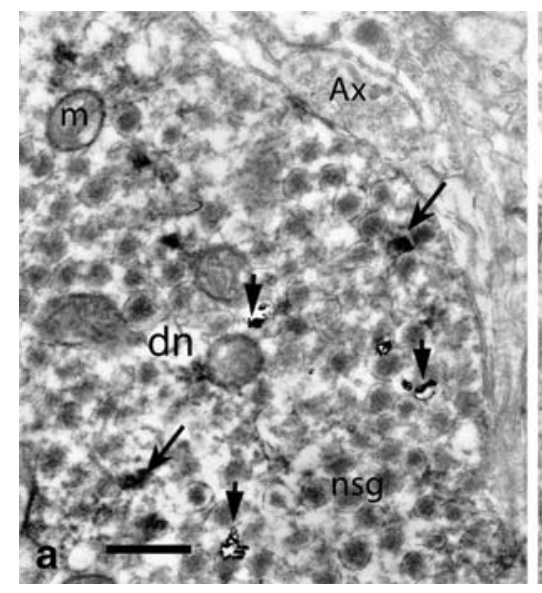

Fig. 4 Neuropil of supraoptic nucleus of the hypothalamus doublelabelled for nNOS (immunoprecipitate - long arrows) and ET-1 (immunogold-silver grains - short arrows). a A fragment of a doublelabelled dendrite (likely to be a primary or varicose dendrite from a bipolar magnocellular neurone) shows abundance of neurosecretory granules (nsg), of which some are nNOS-positive (long arrows); short arrows point to immunoreactivity for ET-1. Note unlabelled axon profile (Ax) making synapse on the double-labelled dendrite. b A doublelabelled axon terminal (At) making asymmetric synapse with unlabelled dendrite spine $(d s)$. The axon terminal contains numerous small agranular synaptic vesicles, membrane of which is labelled with nNOS immunoprecipitate; co-localised immunogold-silver grains of ET-1

et al. 2000; Otukonyong et al. 2000). The axonal synaptic input at the level of the hypothalamic neurosecretory cell bodies of supraoptic and paraventricular nuclei is characterised by the presence of noradrenaline (NA), $\gamma$-aminobutyric acid (GABA) and glutamate (see Buller et al. 1996; Sperrlágh et al. 1998; Theodosis et al. 1998). Therefore it is likely that some of these axonal neurochemical inputs also include ET-1 and nNOS. Studies using hypothalamic explants from rat showed that NO inhibits the release of vasopressin (Yasin et al. 1993), while oxytocin may stimulate the release of NO from oxytocinergic neurones via NA-related mechanisms (Rettori et al. 1997). In rat, ET-1 converting enzyme (ECE; that converts its precursor big ET-1 to mature ET-1) is present in a subpopulation of neurosecretory neurons, including their axons, of the hypothalamo-neurohypophysial tract (Kurokawa et al. 2000). Histochemical evidence suggests that big ET-1 is secreted as a neurohormone from nerve terminals into the neurohypophysial blood vessels (Yamada and Kurokawa 1998). Hypothalamic endocrine nuclei display ET binding, in particular to $\mathrm{ET}_{\mathrm{A}}$ receptors (Kurokawa et al. 1997; Yamada and Kurokawa 1998). Strikingly, increases in circulating levels of ET-1 affect the hypothalamic endocrine nuclei producing predominantly excitatory effects on vasopressin- and oxytocin-neurones (Wall \& Ferguson 1992). A recent study of the rat hypothalamus showed that ET-1 decreases neuronal NA uptake in the anterior hypothalamus and diminishes the uptake in the posterior hypothalamic region (Hope et al. 2008).

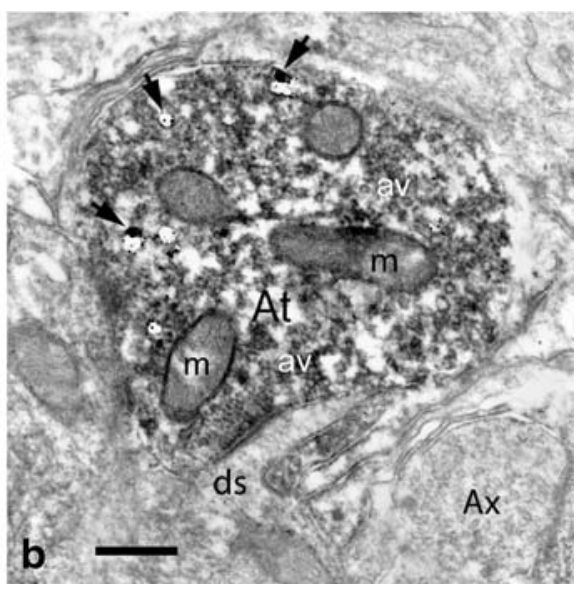

labelling (arrows) are also seen. Note that an adjacent axon profile $(A x)$ containing small agranular synaptic vesicles is unlabelled; $\mathrm{m}$ mitochondria. Bars: $0.5 \mu \mathrm{m}$. Affinity-purified rabbit polyclonal nNOS antibody (SC-1025, Santa Cruz, USA), which does not cross react with NOS2 and NOS3 was used at $0.8 \mu \mathrm{g} / \mathrm{ml}$ in the preembedding ExtrAvidin immunocytochemical method. The rabbit polyclonal ET-1 antibody to human/porcine ET-1 (Sigma, Poole, UK), which does not cross-react with big ET but may with ET-2 and ET-3 was used at 1:1,000 in the preembedding immunogold-silver labelling method as the second immunolabelling. Images A and B are modified from Mukherjee and Loesch, Histochem J 2002, 34:181-187 [Kluwer Academic Publishers], which is kindly acknowledged

In addition to its neuroendocrine involvement the hypothalamus plays an important role in thermoregulation (Feldberg 1965). The potential role of ET-1 as a central mediator of fever has been studied where levels of big ET1, the precursor of ET-1, were measured in cerebral spinal fluid (CSF) from rats after intravenous administration of lipopolysaccharide (LPS). Interestingly, big ET-1 levels in cisternal CSF fell in febrile rats versus controls, but levels were significantly increased in rats that had received ICV administration of the $\mathrm{ET}_{\mathrm{B}}$ antagonist, $\mathrm{BQ788}$. Furthermore, intrahypothalamic injection of ET-1 caused a substantial and long lasting rise in rectal temperature. The authors conclude that LPS-induced fever in rat enhances ET-1 production in the brain (via measurement of big ET-1) and that ET-1 is an endogenous pyrogen (Fabricio et al. 2005).

\section{ET-1 and the PNS/ANS}

\section{Cerebrovascular autonomic nerves}

Although the endothelium is recognized as a major source of ET-1 in the vasculature it was reported that the autonomic perivascular nerves in rat basilar artery are immunopositive for ET-1 with $36 \%$ of the axon profiles (varicosities and intervaricosities) in the adventitia of the rat basilar artery observed at the electron microscopic level being immunolabelled for ET-1 (Loesch et al. 1998). Axon 
varicosities of these ET-1-positive nerve fibres displayed small agranular vesicles $(\sim 42 \mathrm{~nm})$ and large granular vesicles $(\sim 92 \mathrm{~nm})$ with ET-1-labelled cores (Fig. 5a). Subsequent studies focusing on the basilar artery of spontaneously hypertensive rats showed an increase in ET1-positive perivascular axons in such conditions, although these axons usually displayed structural abnormalities (Fig. 5b) (Milner et al. 2000a). Combined immunohistochemical, in situ hybridisation and sensory and sympathetic denervation studies revealed that the ET-1-containing cerebrovascular nerves originate from the sensory and sympathetic components of the trigeminal (TG) and superior cervical (SCG) ganglia and that the ET-1 in a proportion of the TG neurons is co-localised with sensory substance $\mathrm{P}$ (Milner et al. 2000a, b). This suggests that the sensory TG is the more likely source of ET-1-containing perivascular nerves to cerebral arteries than the sympathetic SCG (Milner et al. 2000b).
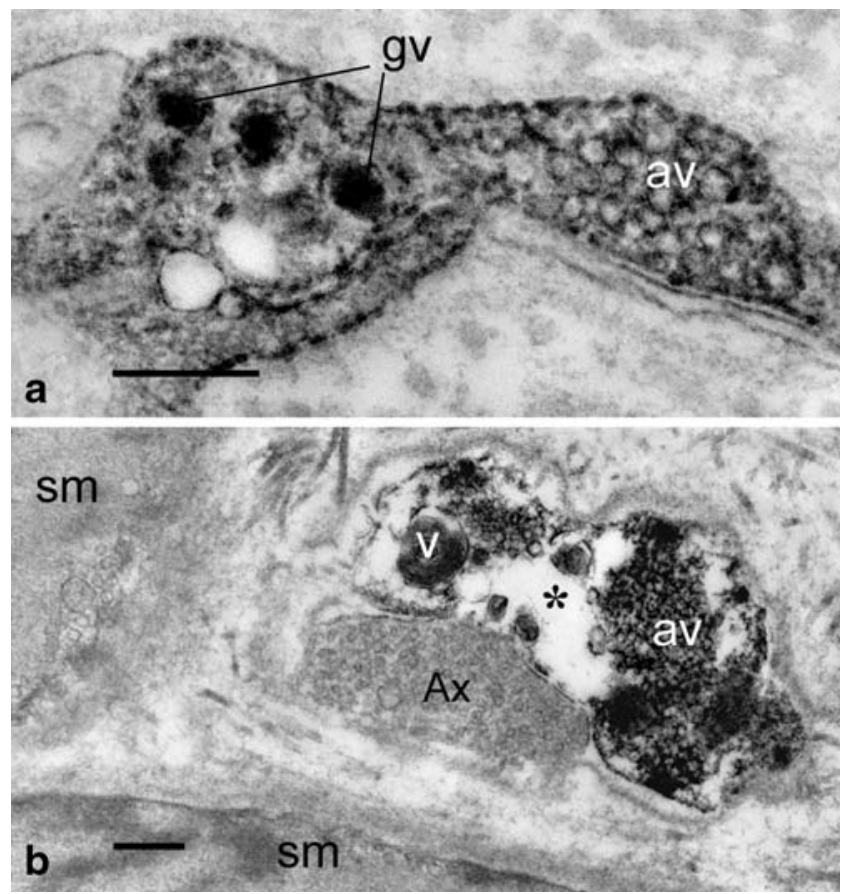

Fig. 5 Perivascular nerve/axon varicosities in basilar artery of a normal $(A)$ and hypertensive $(B)$ rats immunolabelled for ET-1. a Note granular (gv) and agranular (av) vesicles; core of granular vesicles is intensely labelled for ET-1. In B note damaged axon varicosity with clustered agranular vesicles (av), vacuoles with dense material (v), and 'empty' areas of axoplasm (asterisk). Adjacent ET-1-negative varicosity $(\mathrm{Ax})$ is of normal appearance with evenly distributed vesicles. Bars: $0.2 \mu \mathrm{m}$. Rabbit polyclonal ET-1 antibodies to human/porcine ET-1 (a from CRB, Cambridge, UK; b from Sigma, Poole, UK) was used at 1:1,000 in the preembedding PAP method; antibodies do not cross-react with big ET but may with ET-2 and ET-3. A is modified from Loesch et al. Neuroreport 1998, 9:3903-3906 [Lippincott Williams \& Wilkins] and B is from Milner et al. J Vasc Res 2000; 37:39-49 [S Karger AG, Basel/Medical and Science publishers], which is kindly acknowledged
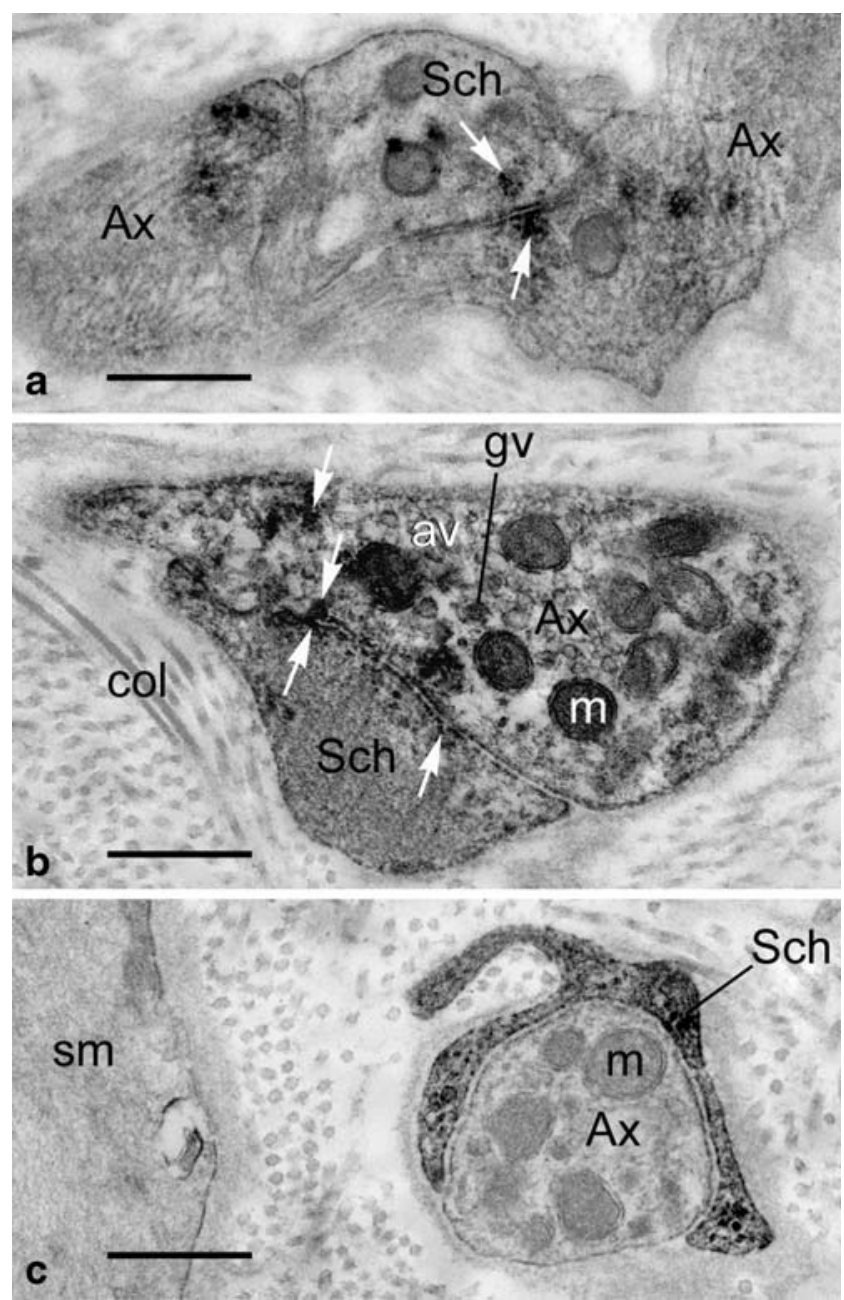

Fig. 6 Capybara basilar artery perivascular nerves labelled (black precipitate) for $\mathrm{ET}_{\mathrm{A}}(\mathrm{A})$ and $\mathrm{ET}_{\mathrm{B}}(\mathrm{B})$ receptors. In $\mathbf{a}$ and $\mathbf{b}$ note axons $(\mathrm{Ax})$ and Schwann cell profiles (Sch) displaying immunoreactivity (arrows) for $\mathrm{ET}_{\mathrm{A}}$ and $\mathrm{ET}_{\mathrm{B}}$ receptors, respectively; some labelling is seen in the granular vesicles. In $\mathrm{C}$ note $\mathrm{ET}_{\mathrm{B}}$ localisation in the Schwann cells only, while associated axon varicosities is negative for $\mathrm{ET}_{\mathrm{B}}$ receptors. Bars: $0.5 \mu \mathrm{m}$. Rabbit polyclonal antibodies $\mathrm{ET}_{\mathrm{A}}$ and $\mathrm{ET}_{\mathrm{B}}$ (Alomone Labs, Jerusalem, Israel) were used at 1:400 in preembedding ExtrAvidin method. The $\mathrm{ET}_{\mathrm{A}}$ receptor antibody (AER001) recognises intracellular (C-terminus) epitope corresponding to amino acid residues 413-426 of rat $\mathrm{ET}_{\mathrm{A}}$ peptide (Accession $\mathrm{P} 26684$ ), while the $\mathrm{ET}_{\mathrm{B}}$ receptor antibody (AER-002) recognises intracellular (i3 loop) epitope corresponding to residues 298-314 of rat $\mathrm{ET}_{\mathrm{B}}$ peptide (Accession P21451). Both antibodies were affinity purified on immobilized antigens. (A-C are modified from Loesch et al., J Mol Histol 2005; 36: 25-34 [Kluwer and Springer Science and Business Media], which is kindly acknowledged)

Since this denervation study suggests that ET-1-positive perivascular nerves of large cerebral arteries may be the projections of primary afferent sensory neurons of the TG this raises the possibility that ET-1 may co-exist with other sensory transmitters such as the neuropeptides substance $\mathrm{P}$ and calcitonin gene-related peptide (CGRP), known to be present in TG sensory nerves projecting to large 
cerebral arteries (Suzuki et al. 1989). Our own electronimmunocytochemical study in capybara, the largest rodent, revealed that cerebrovascular nerves contain both $\mathrm{ET}_{\mathrm{A}}$ and $\mathrm{ET}_{\mathrm{B}}$ receptors (Fig. 6), suggesting that neurotransmission involving ET-1 occurs in cerebral arteries (Loesch et al. 2005). Patients with cerebrovascular disease exhibit an increased expression of $\mathrm{ET}_{\mathrm{B}}$ receptors (Hansen-Schwartz 2004; Hansen-Schwartz et al. 2002) and the expression of $\mathrm{ET}_{\mathrm{B}}$ receptors has also been described in perivascular nerves of microvessels of the sensorimotor cortex and hippocampus after brain trauma (Kallakuri et al. 2007) where it is suggested that $\mathrm{ET}_{\mathrm{B}}$ receptor expression is linked with both vasoconstriction and attenuation of ET-1 synthesis and availability.

A number of studies describe in detail a variety of pharmacological and physiological effects linked with ET-1 and the adventitial region of cerebral vessels. These include experiments with the injections of ET-1 to the cisterna and vertebral artery (Mima et al. 1989) as well as using wellestablished cerebral artery occlusion models, mostly of the middle cerebral artery in the rat or mouse simulating stroke and ischemic conditions in adjacent brain tissue (Ahn et al. 2002; Callaway et al. 2003; Gresle et al. 2006; Gupta et al. 2006; Miller et al. 2006). In these models, localised microinjection of ET-1 affects the perivascular but not the lumenal compartment of the middle cerebral artery causing vasoconstriction. ET-1 was proposed as a major cause of cerebral vasospasm in subarachnoid hemorrhage (SAH), and having stronger vasoconstrictor effects than ET-2 and ET-3 (Zimmermann and Seifert 1998). This phenomenon (and/or similar ones) may also shed some light on the possible involvement of ET-1-containing cerebrovascular nerves in vasoconstriction where stimulation of such nerves releases neural ET-1 resulting in vasoconstriction of the cerebral artery that they innervate. This hypothesis might also be extended to other vascular beds including the rat femoral artery, where sustained arterial constriction following prolonged exposure to perivascular ET-1 was reported (Ahn et al. 2002).

In addition to adventitial cerebrovascular nerves the adventitial Schwann cells of the vessel wall are also implicated in certain mechanisms related to the action of ET-1. For example, in the adventitia of the middle cerebral artery of man a close apposition of ET-1-positive Schwann cells and ET-1 negative axon varicosities have been observed suggesting an interaction between these cells (Loesch et al. 2004). There is a suggestion that glial cells, such as astrocytes, are the main local source of ET-1 in the subarachnoid space following hemorrhage and cerebral ischemia (Pluta et al. 1997). Therefore, the possibility exists that ET-1 derived from glial cells, rather than from the cerebral vascular endothelium, is the likely participant

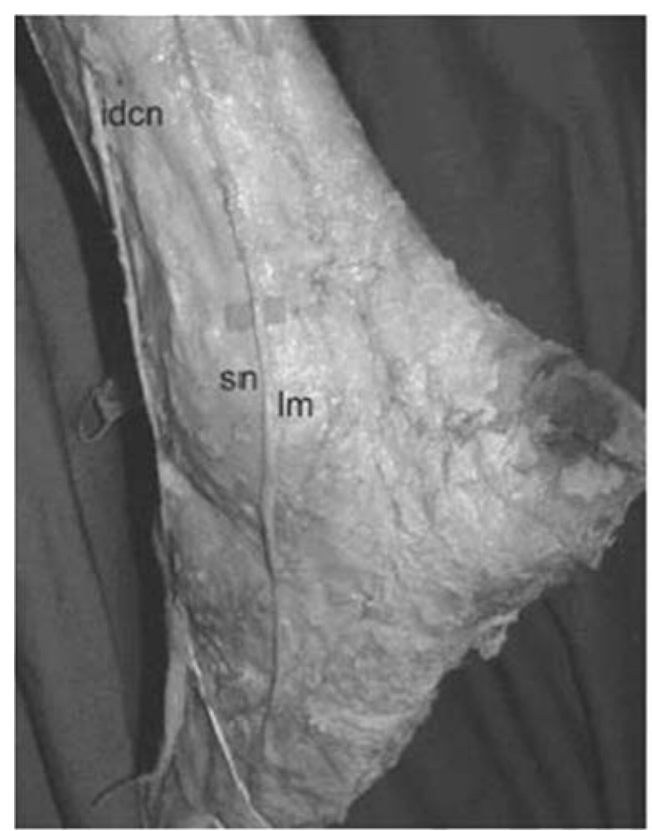

Fig. 7 Endothelin and its receptors on human sural nerve. a Location of human sural nerve: (From Aktan Ikiz et al. 2005) sn:sural nerve, lm: lateral malleolus, idcn: intermediate dorsal cutaneous nerve. b Distribution of ET-1, $\mathrm{ET}_{\mathrm{A}}$ and $\mathrm{ET}_{\mathrm{B}}$ receptors on human sural nerve sections revealed by in vitro autoradiography using radiation-sensitive film (low resolution). c Microscopic localisation of ET-1 on a section of human sural nerve. Left panel is a dark-field illumination, 'high resolution'
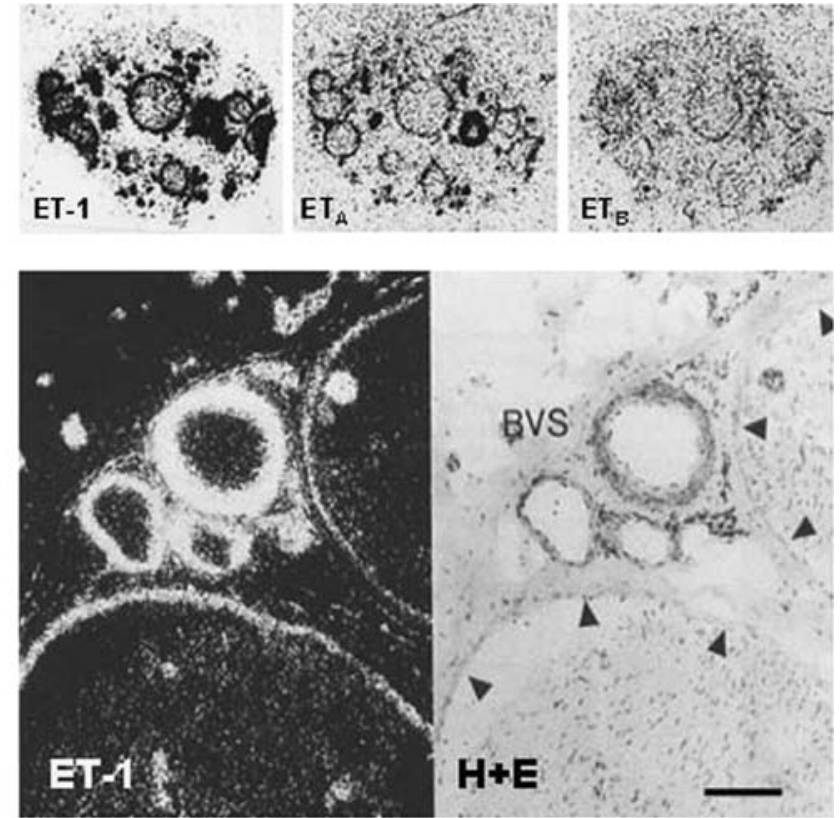

autoradiograph of a section incubated in ${ }^{125}$ I-labelled ET-1 and detected using nuclear emulsion where white grains show receptor binding sites. Right panel is the haemotoxylin and eosin stained tissue. There is strong binding to the epineurial vessels $(B V S)$, perineurium (arrowheads) and vasa nervorum (small cell clusters within the nerve fascicles surrounded by the perineurium). Scale bars $=2 \mathrm{~mm}$ for autoradiographs in $\mathrm{B}$ and $50 \mu \mathrm{m}$ for C (B and C modified from Dashwood and Thomas 1997) 
in certain cerebrovascular disorders (Pluta et al. 1997). It is also recognised that ET-1 plays a role in Schwann cells during nerve development and degeneration and that ET-1 can stimulate or inhibit the release of neurotransmitter(s) from sympathetic neurons (Damon 1999; Barti-Mattera et al. 2001; Pomonis et al. 2001). Taken together the data regarding ET-1-positive perivascular nerves, ET-1-positive Schwann cells, and the location of $\mathrm{ET}_{\mathrm{A}}$ and/or $\mathrm{ET}_{\mathrm{B}}$ receptors on these cells should not be overlooked, in particular in regard to the vasomotor control of cerebral vessels. It is likely that these perivascular nerves and Schwann cells are potential sources of neural ET-1 in the vessel wall, where they play a role perhaps as important as that of endothelium-derived ET-1.

\section{Neurovascular actions of ET-1 in peripheral nerve}

While identifying neural ET-1-containing sites histologically, such studies generally fail to provide supporting evidence of function (Loesch 2005; Tsui and Dashwood 2005). Concluding that ET-1-mediated effects are 'neuronal', based purely on the visualisation of the peptide in nerve tissue overlooks the potential that such effects may be vascular in origin. Reduced blood supply to nerve and subsequent ischaemia may have a pronounced effect on nerve function. Thus, certain neurotransmitter actions may be secondary to ET-1-induced constriction of the endoneural vessels and vasa nervorum. For example, local application of ET-1 to rat sciatic nerve causes reduced axonal conduction, due to a localised effect on epineurial microvessels and subsequent ischaemia of the nerve (Cameron et al. 1994). A later report, using a diabetic rat model, showed that endogenous ET-1 plays a potential role in diabetic neuropathy via an action on nerve blood perfusion (Stevens and Tomlinson 1995). Here, using streptozotocin-induced diabetic rats, after 6 weeks of untreated diabetes, infusion of an $\mathrm{ET}_{\mathrm{A}}$ receptor antagonist caused a significant increase in sciatic nerve conduction whereas in non-diabetic rats it was ineffective. In diabetic rats sciatic nutritive endoneurial blood flow was reduced, an effect that was significantly ameliorated by $\mathrm{ET}_{\mathrm{A}}$ receptor antagonist treatment. In nondiabetic rats antagonist treatment had no effect on blood flow, suggesting that ET-1 is not involved in the control of nerve blood flow in normal rats but makes a major contribution to the perfusion deficit in experimental diabetes raising the possibility that ET-1 receptor blockade may have therapeutic potential in diabetic patients (Stevens and Tomlinson 1995).These observations may be relevant to data obtained in human sural nerve biopsies where, using in vitro receptor autoradiography, $\left[{ }^{125} \mathrm{I}\right]$-ET-1 binding was associated with various structures, in particular the perineurium, endoneurial vessels and vasa nervorum (Fig. 7; Dashwood and Thomas 1997). This binding was reduced (competitively) when sural nerve sections were incubated in the presence of the mixed ET receptor antagonist, bosentan, providing evidence that (like the diabetic rat model) the 'neuropeptide' role of ET-1 may be mediated via 'neurovascular' effects where altered nerve conduction is associated with an ET-1-induced reduction in nerve blood flow and subsequent nerve ischaemia (Dashwood and Thomas 1997).

\section{Conclusions}

Apart from the well-established vasoactive and proliferative effects of the endothelins, in particular ET-1, it is suggested that this peptide also possesses neurotransmitter activity. While a neuropeptide role for ET-1 is supported by its histological identification in both the central and peripheral nervous systems caution is needed in interpretation of results since certain 'neural' effects of this peptide may be due to its potent neurovascular action. However, the therapeutic potential of endothelin receptor subtypeselective antagonists in a number of neural conditions remains regardless of their site of action.

Acknowledgements MRD acknowledges the continued support from the Department of Clinical Biochemistry, Royal Free Hospital and AL support from the Wellcome Trust.

Open Access This article is distributed under the terms of the Creative Commons Attribution Noncommercial License which permits any noncommercial use, distribution, and reproduction in any medium, provided the original author(s) and source are credited.

\section{References}

Ahn YM, Gajdusek C, London S, Moon CT, Oh CW, Mayberg MR (2002) Sustained arterial narrowing after prolonged exposure to perivascular endothelin. Neurosurgery 50:843-848

Aktan Ikiz ZA, Ucerler H, Bilge O (2005) The anatomic features of the sural nerve with an emphasis on its clinical importance. Foot Ankle Int 26:560-567

Arai H, Hori S, Aramori I, Ohkubo H, Nakanishi S (1990) (1990) Cloning and expression of a cDNA encoding and endothelin receptor. Nature 348:730-732

Barti-Mattera LN, Harwalkar S, Huges B, Wilkins PL, Almhanna K (2001) Proliferative and morphological effects of endothelins in Schwann cells: roles of $\mathrm{p} 38$ mitogen-activated protein kinase and $\mathrm{Ca}^{2+}$-independenta phospholipase $\mathrm{A}_{2}$. J Neurochem 79:11361148

Buller KM, Khanna S, Sibbald JR, Day TA (1996) Central noradrenergic neurons signal via ATP to elicit vasopressin responses to haemorrhage. Neuroscience 73:637-642

Callaway JK, Lawrence AJ, Jarrott B (2003) AM-36, a novel neuroprotective agent, profoundly reduces reactive oxygen species formation and dopamine release in the striatum of conscious rats after endothelin-1-induced middle cerebral artery occlusion. Neuropharmacology 44:787-800 
Cameron NE, Dines KC, Cotter MA (1994) The potential contribution of endothelin-1 to neurovascular abnormalities in streptozotocindiabetic rats. Diabetologia 37(12):1209-1215

Cao W, Kuwaki T, Unekawa M, Ling G, Terui N, Kumada M (1993) Action of endothelin-1 on vasomotor neurons in rat rostral ventrolateral medulla. J Cardiovas Pharmacol 22(Suppl. 8):S196S198

Costa A, Napri RE, Polatti F, Poma A, Grossman AB, Nappi G (2000) Stimulating effect of HIV-1 coat protein gp120 on corticotropinreleasing hormone and arginine vasopressin in the rat hypothalamus: involvement of nitric oxide. Exp Neurol 166:376-384

D'Amico M, Dashwood MR, Warner TD (1996) Endothelin-1 and the periaqueductal gray area of the rat: an autoradiographic and functional pharmacological study. Br J Pharmacol 118:21-26

Damon DH (1999) Endothelin and post-ganglionic sympathetic neurons. Clin Exp Pharmacol Physiol 26:1000-1003

Dashwood MR, Feldberg W (1979) Central inhibitory effect of released opiate peptides on adrenal medulla, revealed by naloxone in the cat. J Physiol 290:22P-23P

Dashwood MR, Thomas PK (1997) Neurovascular [125I]-ET-1 binding sites on human peripheral nerve. Endothelium 5(2):119-123

Fabricio AS, Rae GA, D'Orléans-Juste P, Souza GE (2005) Endothelin-1 as a central mediator of LPS-induced fever in rats. Brain Res 1066(1-2):92-100

Feldberg W (1965) A new concept of temperature control in the hypothalamus. Proc R Soc Med 58:395-404

Feldberg W, Sherwood SL (1954) Injections of drugs into the lateral ventricle of the cat. J Physiol (Lond) 123:148-167

Franco-Cereceda A, Rydh M, Lou YP, Dalsgaard CJ, Lundberg JM (1991) Endothelin as a putative sensory neuropeptide in the guinea-pig: different properties in comparison with calcitonin gene-related peptide. Regul Pept 32:253-265

Gajkowska B, Viron A (1996) Localization of endothelin-like immunoreactivity in the hypothalamo-neurohypophysial system of the rat after ischemia. Folia Neuropathol 34(4):173-177

Garthwaite J, Boulton CL (1995) Nitric oxide signalling in the central nervous system. Ann Rev Physiol 57:683-706

Giaid A, Gibson SJ, Ibrahim NBN, Legon S, Bloom SR, Yanagisawa M, Masaki T, Varndell IM, Polak JM (1989) Endothelin 1, an endothelium-derived peptide, is expressed in neurones of the human spinal cord and dorsal root ganglia. Proc Natl Acad Sci USA 86:7634-7638

Giaid A, Gibson SJ, Herrero MT, Gentleman S, Legon S, Yanagisawa M, Masaki T, Ibrahim NBN, Roberts GW, Rossi ML, Polak JM (1991) Topographical localization of endothelin mRNA and peptide immunoreactivity in neurones of the human brain. Histochemistry 95(3):303-314

Gresle MM, Jarrott B, Jones NM, Callaway JK (2006) Injury to axons and oligodendrocytes following endothelin-1-induced middle cerebral artery occlusion in conscious rats. Brain Res 1110:13-22

Gulati A, Kumar A, Morrison S, Shahani BT (1997) Effect of centrally administered endothelin agonists on systemic and regional blood circulation in the rat: role of sympathetic nervous system. Neuropeptides 31(4):301-309

Gupta S, Akerman S, van den Maagdenberg AMJM, Saxena PR, Goadsby PJ, MaassenVanDenBrink A (2006) Intravital microscopy on a closed cranial window in mice: a model to study trigeminovascular mechanisms involved in migraine. Cephalalgia 26:1294-1303

Hansen-Schwartz J (2004) Receptor changes in cerebral arteries after subarachnoid haemorrhage. Acta Neurol Scand 109:33-44

Hansen-Schwartz J, Szok D, Edvinsson L (2002) Expression of ET(A) and $\mathrm{ET}(\mathrm{B})$ receptor mRNA in human cerebral arteries. Br J Neurosurg 16:149-153

Hekmatpanah J (2007) Cerebral microvessel perfusion and pathologic alteration of the brain during drowsiness and coma, caused by brain tumor (A laboratory study in rats). Surg Neurol. 67(6):564 571

Hemsen A, Lundberg JM (1991) Presence of endothelin-1 and endothelin-3 in peripheral tissues and central nervous system of the pig. Regul Pept 36:71-83

Hope SI, Schmipp J, Rossi AH, Bianciotti LG, Vatta MS (2008) Regulation of the neuronal norepinephrine transporter by endothelin- 1 and -3 in the rat anterior and posterior hypothalamus. Neurochem Int 53:207-213

Horowitz MJ, Bloch KD, Kim NB, Amico JA (1994) Expression of the endothelin-1 and oxytocin genes in the hypothalamus of the pregnant rat. Brain Res 648:59-64

Hoyle CHV, Burnstock G (1995) Criteria for defining enteric neurotransmitters. In: Gaginella TS (ed) Handbook of Methods in Gastrointestinal Pharmacology. CRC, Boca Raton, pp 123 140

Jiang YM, Yuan WJ, Xiang ZH, Miao WM, Lin L, Jiao BH (2000) Effect of scald on gene transcription and content of endothelin-1 in supraoptic nucleus of rat hypothalamus. Sheng Li Xue Bao 52:385-389

Kallakuri S, Kreipke CW, Rossi N, Rafols JA, Petrov T (2007) Spatial alterations in endothelin receptor expression are temporally associated with the altered microcirculation after brain trauma. Neurol Res 29:362-368

Khodorova A, Montmayeur JP, Strichartz GJ (2009) Endothelin receptors and pain. J Pain 10(1):4-28

Khodorova A, Navarro B, Jouaville LS, Murphy JE, Rice FL, Mazurkiewicz JE, Long-Woodward D, Stoffel M, Strichartz GR, Yukhananov R, Davar G (2003) Endothelin-B receptor activation triggers an endogenous analgesic cascade at sites of peripheral injury. Nat Med. 9(8):1055-1061

Knuepfer MM, O'Brien D, Hoang D, Gan Q, Song C (1994) Central sympathetic control of spinal endothelin release in the rat. Eur J Pharmacol 259:305-308

Kostreva DR (1983) Functional mapping of cardiovascular reflexes and the heart using 2-[14C]deoxyglucose. Physiologist. 26 (6):333-350

Krsmanovic LZ, Stojilkovic SS, Balla T, Al-Damluji S, Weiner RI, Catt KJ (1991) Receptors and neurosecretory actions of endothelin in hypothalamic neurons. Proc Natl Acad Sci USA 88:11124-11128

Kumar A, Morrison S, Gulati A (1997) Effect of ETA receptor antagonists on cardiovascular responses induced by centrally administered sarafotoxin $6 \mathrm{~b}$ : role of sympathetic nervous system. Peptides 18(6):855-864

Kurokawa K, Yamada H, Liu Y, Kudo M (2000) Immunohistochemical distribution of the endothelin-converting enzyme-1 in the rat hypothalamo-pituitary axis. Neurosci Letters 284:81-84

Kurokawa K, Yamada H, Ochi J (1997) Topographical distribution of neurons containing endothelin type A receptor in the brain. J Comp. Neurol 389:348-360

Lee M, De La Monte S, Ng S, Block K, Quertermous T (1990) Expression of the potent vasoconstrictor endothelin in the human central nervous system. J Clin Invest 86:141-147

Lincoln J, Hoyle CHV, Burnstock G (1997) Nitric Oxide in Health and Disease. (Series ed. Lucy JA). Cambridge University Press, Cambridge, UK.

Loesch A (2005) Localisation of endothelin-1 and its receptors in vascular tissue as seen at the electron microscopic level. Curr Vasc Pharmacol 3:381-392

Loesch A, Burnstock G (2002) Endothelin in human cerebrovascular nerves. Clin Sci 103(Suppl. 48):404S-407S

Loesch A, Kilford L, Kingsbury A (2004) Endothelin in Schwann cells of middle cerebral artery in a case of multiple system atrophy with autonomic failure. Biomed Res (India) 15(2): 157-159 
Loesch A, Gajkowska B, Dashwood MR, Fioretto ET, Gagliardo KM, de Lima AR, Ribeiro AACM (2005) Endothelin-1 and endothelin receptors in the basilar artery of the capybara. J Mol Histol 36:25-34

Loesch A, Milner P, Burnstock G (1998) Endothelin in perivascular nerves. An electron-immunocytochemical study of rat basilar artery. NeuroReport 9:3903-3906

Macrae IM, McAuley MA, Robinson MJ, Reid JL, McCulloch J (1991a) Endothelin-1-induced hypertension: a consequence of medullary ischaemia? J Cardiovasc Pharmacol. 17(suppl 7):S496-499

Macrae I, Robinson M, McAuley M, Reid J, McCulloch J (1991b) Effects of intracisternal endothelin-1 injection on blood flow to the lower brain stem. Eur J Pharmacol. 203(1):85-91

Macrae IM, Robinson MJ, Graham DI, Reid JL, McCulloch J (1993) Endothelin-1-induced reductions in cerebral blood flow: dose dependency, time course, and neuropathological consequences. J Cereb Blood Flow Metab. 13(2):276-284

McAuley MA, Breu V, Graham DI, McCulloch J (1996) The effects of bosentan on cerebral blood flow and histopathology following middle cerebral artery occlusion in the rat. Eur $\mathrm{J}$ Pharmacol 307:171-181

Mickey I, Kilford L, Kingsbury A, Loesch A (2002) Endothelin in the middle cerebral artery: a case of multiple system atrophy. Histochem J 34:469-477

Miller AA, Dusting GJ, Roulston CL, Sobey CG (2006) NADPHoxidase activity is elevated in penumbral and non-ischemic cerebral arteries following stroke. Brain Res 1111:111-116

Mima T, Yanagisawa M, Shigeno T, Saito A, Goto K, Takakura K, Masaki T (1989) Endothelin acts in feline and canine cerebral arteries from the adventitial side. Stroke 20(11):1553-1556

Milner P, Loesch A, Burnstock G (2000a) Neural endothelin in hypertension: increased immunoreactivity in ganglia and nerves to cerebral arteries of the spontaneously hypertensive rat. J Vasc Res 37:39-49

Milner P, Loesch A, Burnstock G (2000b) Endothelin immunoreactivity and mRNA expression in sensory and sympathetic neurones following selective denervation. Int J Dev Neurosci 18:722-734

Mosqueda-Garcia R, Stainback R, Fernandez-Violante R, Hamakubo $\mathrm{T}$ (1995) Cardiovascular effects of endothelin injected into brain nuclei regulating vasopressin release. J Cardiovasc Pharmacol 26 (Suppl 3):S159-S162

Mukherjee AB, Loesch A (2002) Co-localisation of nitric oxide synthase and endothelin in the rat supraoptic nucleus. Histochem J 34:181-187

Nabhen SL, Perfume G, Battistone MA, Rossi A, Abramoff T, Bianciotti LG, Vatta MS (2009) Short-term effects of endothelins on tyrosine hydroxylase activity and expression in the olfactory bulb of normotensive rats. Neurochem Res 34:953-63

Naidoo V, Naidoo S, Mahabeer R, Raidoo DM (2004a) Cellular distribution of the endothelin system in the human brain. J Chem Neuroanat. 27(2):87-98

Naidoo V, Naidoo S, Raidoo DM (2004b) Immunolocalisation of endothelin-1 in human brain. J Chem Neuroanat. 27(3):193-200

Nakamura S, Naruse M, Naruse K, Shioda S, Nakai Y, Uemura H (1993) Colocalization of immunoreactive endothelin-1 and neurohypophysial hormones in the axons of the neural lobe of the rat. Endocrinology 132:530-533

Ng YK, Xue YD, Wong PT (1999) Different distributions of nitric oxide synthase-containing neurons in the mouse and rat hypothalamus. Nitric Oxide 3:383-392

Otukonyong EE, Okere CO, Johnstone LE, Murata T, Kaba H, Higuchi T (2000) Effect of suckling on NADPH-diaphorase (Nitric oxide synthase, NOS) reactivity and NOS gene expression in the paraventricular and supraoptic nuclei of lactating rats. $\mathrm{J}$ Neuroendocrinol. 12(10):1001-1008

Patel TR, McCauley MA, MaCulloch J (1996) Endothelin receptor mediated constriction and dilatation in feline cerebral resistance arterioles in vivo. Eur J Pharmacol 307(1):41-48
Pluta RM, Boock RJ, Afshar JK, Clouse K, Bacic M, Ehrenreich H, Oldfield EH (1997) Source and cause of endothelin-1 release into cerebrospinal fluid after subarachnoid hemorrhage. J Neurosurg 87:287-293

Pomonis JD, Rogers SD, Cm P, Ghilardi JR, Mantyh PW (2001) Expression and localization of endothelin receptors: implications for the involvement of peripheral glia in nociception. J Neurosci 21:999-1006

Rebello S, Roy S, Saxena PR, Gulati A (1995) Systemic hemodynamic and regional circulatory effects of centrally administered endothelin-1 are mediated through ETA receptors. Brain Res 676 (1): $141-150$

Reid IA (1994) Role of nitric oxide in the regulation of renin and vasopressin secretion. Front Neuroendocrinol 15:351-358

Rettori V, Canteros G, McCann SM (1997) Interaction between NO and oxytocin: influenc on LHRH release. Braz J Med Biol Res 30:453-457

Rubino A, Loesch A, Burnstock G (1999) Nitric oxide and endothelin-1 in coronary and pulmonary circulation. Int Rev Cytol 189:59-93

Shepherd GM (2003) The single capillary and the active brain. Proc Natl Acad Sci 100:12535-6

Shinmi O, Kimura S, Sawamura T, Sugita Y, Yoshizawa T, Uchiyama Y, Yanagisawa M, Goto K, Masaki T, Kanazawa I (1989) Endothelin-3 is a novel neuropeptide: isolation and sequence determination of endothelin- 1 and endothelin- 3 in porcine brain. Biochem Biophys Res Commun 164:587-593

Snyder SH, Bredt DS (1992) Biological roles of nitric oxide. Sci Am 266(5):68-71

Sokoloff L (1978) Local cerebral energy metabolism: its relationships to local functional activity and blood flow. Ciba Found Symp. 56:171-197

Sokoloff L (1984) Mapping local functional activity by measurement of local cerebral glucose utilization in the central nervous system of animals and man. Harvey Lect 79:77-143

Sperrlágh B, Sershen H, Lajtha A, Vizi ES (1998) Co-release of endogenous ATP and $[3 \mathrm{H}]$ noradrenaline from rat hypothalamic slices: origin and modulation by $\alpha 2$-adrenoceptors. Neuroscience 82:511-520

Stevens EJ, Tomlinson DR (1995) Effects of endothelin receptor antagonism with bosentan on peripheral nerve function in experimental diabetes. Br J Pharmacol. 115(2):373-379

Suzuki N, Hardebo JE, Owman C (1989) Origins and pathways of cerebrovascular nerves storing substance $\mathrm{P}$ and calcitonin generelated peptide in rat. Neuroscience 31:427-438

Theodosis DT, El Majdoui M, Pierre K, Poulain DA (1998) Factors governing activity-dependent structural plasticity of the hypothalamo-neurohypophysial system. Cell Mol Neurobiol 18:285-298

Tsui JC, Dashwood MR (2005) A role for endothelin-1 in peripheral vascular disease. Curr Vasc Pharmacol 3:325-332

Uemura H, Naruse M, Nakamura S, Naruse K, Yamamoto T, Demura $H$, Hirohama $T$ (1994) Immunoreactive endotheli-1 in the neural lobe of the rat pituitary following hemorrhag and dehydration. Endocr J 41:685-691

Wall KM, Ferguson AV (1992) Endothelin acts at the subfornical organ to influence the activity of putative vasopressin and oxytocin-secreting neurons. Brain Res 586:111-116

Wang H, Morris JF (1999) Effects of oestrogen upon nitric oxide synthase NADPH-diaphorase activity in the hypothalamoneurohypophysial system of the rat. Neuroscience 88:151158

Yamada H, Kurokawa K (1998) Histochemical studies on endothelin and the endothelin-A receptor in the hypothalamus. J Cardiovasc Pharmacol. 31(Suppl 1):S215-S218

Yanagisawa M, Kurihara H, Kimura S, Tomobe Y, Kobayashi M, Mitsui Y, Yazaki Y, Goto K, Masaki T (1988) A novel potent 
vasoconstrictor peptide produced by vascular endothelial cells. Nature 332:411-415

Yasin S, Costa A, Navarra P, Pozzoli G, Kostoglou-Athanassiou I, Forsling MJ, Grossman A (1994) Endothelin-1 stimulates the in vitro release of neurohypophysial hormones, but not corticotropin-releasing hormone, via ETA receptors. Neuroendocrinology 60:553-558

Yasin S, Costa A, Trainer P, Windler R, Forsling MJ, Grossman A (1993) Nitric oxide modulates the release of vasopressin from rat hypothalamic explants. Endocrinology 133:1466-1469
Yoshizawa T, Shinmi O, Giad A, Yanagisawa M, Gibson SJ, Kimura S, Uchiyama Y, Polak JM, Masaki T, Kanazawa I (1990) Endothelin: a novel peptide in the posterior pituitary system. Science 274:462-464

Zimmermann M, Seifert V (1998) Endothelin and subarachnoid hemorrhage: an overview. Neurosurgery 43(4):863-875

Zochodne DW, Ho LT, Gross PM (1992) Acute endoneurial ischemia induced by epineurial endothelin in the rat sciatic nerve. Am J Physiol. 263(6 Pt 2):H1806-1810 